\title{
An Analysis of Agent's Otherness Existence in Anne of Green Gables
}

\author{
Siyou Zhang ${ }^{1,}$, Peijun $\mathrm{Yu}^{1}$ \\ ${ }^{1}$ Wuhan University of Science and Technology, Wuhan, Hubei Province, China \\ a1585143263@qq.com
}

Keywords: Anne; agent; otherness existence; unconsciousness.

\begin{abstract}
Jacques Lacan (1901-1981) is the greatest psychologist to western literature in the 20th century. He combined Freud's Unconscious Theory with Saussure's Structural Linguistics and pointed out that unconsciousness existed within the society and the environment rather within the agent itself. It is the discourse of others, that is, the unconsciousness of the agent is actually the discourse of others. The existence of the agent is pursued by others. The thesis is based on Lacan's Unconscious Theory. Through the analysis of Anne's Otherness existence, we can study the Otherness existence of the author. .
\end{abstract}

\section{Introduction}

Lucy Montgomery, a famous Canadian woman writer, is famous for her Anne of Green Gables. Anne is the protagonist in this novel. She is alone and lonely, but she also has love, dream and gratitude. The stories of Anne's growth-up bring people spiritual enlightenment. The researcher found that previous studies on this work can be divided into three categories: in perspective of feminist, some studies analyze the image of Anne; in perspective of children's literature, that is, bildungsroman, some studies analyze this novel; in perspective of prototype, some studies comparatively analyze the characters in this novel and those in Greek mythology or the Bible. However, few studies have been carried out to focus on Anne's status of an orphan and her strong social recognition. Even if some scholars have studied on this novel in perspective of structuralism or post-structuralism, few of them combine with the phenomena of unconsciousness. This paper thoroughly analyzes Anne's seeking for self-awareness in perspective of Lacan's unconsciousness theory, and deeply analyzes the characters' inner agent's otherness existence, which reveals the author's agent's otherness existence.

\section{The Development of Unconsciousness Theory}

"Unconsciousness" is the core idea of an Austrian psychologist, Sigmund Freud who proposed psychoanalysis. Unconsciousness and consciousness are psychologically opposite. Consciousness refers to everything that an individual perceive through thoughts, memories, or recall, etc. Unconsciousness is the opposite, which refers to everything that an individual cannot perceive through thoughts, memories, or recall, etc. In the present paper, unconsciousness is not only a psychological term, but a term with linguistics and literary definition which is based on psychology. Unconsciousness mainly refers to everything that are resisted and repressed by social norms and customs, which cannot be transformed into consciousness. They are mainly the desires that cannot be allowed by social customs, habits, morality and laws. These desires are suppressed by sensibility while an individual is sober. Thus, they are not revealed. But these desires conflict with other social customs, morality and laws. The individuals hide the impermissible desire at an unconscious level through self-regulation. However, these conflicts have not been resolved. The individuals would unconsciously do something to satisfy their desires. This is the right unconscious theory proposed by Freud: an individual's behavior will be affected by his unconsciousness, which would also subtly influence the development of an individual's behaviors.

Freud pointed out that the unconscious influence of individual behavior is primarily gained by sexual desire which would satisfy his desire. An individual's main desire is sexual desire. This pansexualism is contradicted by his successor Jacques Lacan (1901-1981). Lacan inherited and 
developed Freud's unconscious theory, and made it philosophical. He proposed that unconsciousness is the real element of an individual and it is manifested by the language structure. Lacan combined Freud's psychoanalysis and Saussure's theory of language structure. He supposed that unconsciousness has language structure. By studying unconscious language structure and operation regulations, we could discover the motivations and purposes of human's language and behavior. (ZHAN Junfeng, 2012) Meanwhile, the study of human's language and behavior can also reveal the structure and operation regulations of unconsciousness, and resolve the motivations and purposes of individual behavior.

In addition, Lacan proposed that human' agent is split. The agent cannot fully construct itself. It should be constructed by other objects. It is the imperfections caused by split that contribute to unlimited development for individuals. Therefore, individuals can consistently develop through other objects' split and complement. This kind of unlimited possibility of development makes life wonderful. For instance, cell differentiation is to break the complete status and to grow through outside complements. In perspective of psychoanalysis, this phenomenon is to unconsciously accumulate an individual's unlimited desire. The biological and psychological similarity shows the magic of nature. Some scholars proposed that the core idea of Lacan's theory is loss and fragmentation. The literary loss in Lacan's theory refers to the split individuals. Lacan supposed that literature could seize our desire of returning to the original status and gain the sense of completeness even if it is temporary. (ZHANG Junmei, 2011) This paper focuses on Anne's language and behaviors, which amins to discover the unconscious structure and operation rules of her behaviors and to study on agent's existence mode, that is, otherness existence. Thereby, this paper can explore otherness existence in the whole novel.

\section{Analysis of Anne's Otherness Existence}

In this novel, Anne is the protagonist. She is a great personality with long red hair and freckles. People used to call her "Red hair Annie". Anne lost her parents at an early age; she is a helpless orphan. She has been kept by Mrs. Thomas and Mrs. Hemutter as a babysitter. Due to some misfortune, Anne then goes to the orphanage. Four months later, Anne has been kept by Matthew and Marilla. She has no friends, no family. The experience in youth makes Anne constantly seek self-existence in loneliness, and hope to be recognized and concerned.

Imaginative Anne. Before being kept by Matthew and Marilla, Anne has never enjoyed the warmth of home and concerns. Therefore, she often imagines in order to gain the sense of existence. Annie has two fantasy friends. One is the figure reflected by glass. Anne supposes that she is Cady Morri. They are good friends and keep no secrets from each other. Cady Morri takes with Anne and they go to a happy kingdom together. Then, Anne goes to Mrs. Hemutter's home and she has to break up with Cady. They cry, and they say goodbye to each other. In the Hemutter's, she imagines that the valley is a girl, and names Ruiaolaite. Soon, they become friends and chat and play with each other. Anne has no friends. The imaginary friends are "others". Anne's concern on these two friends is her recognition to agent's consciousness. The otherness recognition and perception help to realize her agent's existence. In addition, Anne also imagines about other scenarios, such as her own home, her appearance, her friends' appearances, etc. All these imaginations give Anne great self-satisfaction. This way to be recognized by others is the main approach to Anne's self-existence.

An Anne likes nominating. Lacan supposed that nomination is an individual has to accept a symbol (the objects interpellated by adults). (ZHANG Yibing, 2006) Anne thinks that this kind of recognition is an approach to conquer others. After marking everything with the stigma of Anne, she dominates others in order to gain a strong sense of self-existence. For instance, Anne names the original "avenue" as "Baile Road", "Barry's pond" as "Jingliang lake". She also names herself "Cody Maria". In addition, "Ghost Forest", "Lover trail" and some other nominations are all made by Anne. All these are marked by Anne, that is, "Anne style". According to Lacan's theory, "agent" is the discourse subject. Thus, agent is the production of language. It is constructed through language and exists in language. (HUANG Hanping, 2006) Being an important part of agent's language, others' names play an essential role in the construction of agent. Annie's nominations are to build her own 
consciousness. Making others' names her own language not only helps to dominate herself, but also to conquer others. A series of others' and agent's language make Anne's existence more prominent.

Garrulous Anne. Anne garrulous narration is the main line of the whole novel. It is mainly completed by Anne's narrative language. The garrulous Anne makes Marilla irritable. Thus, she often accuses Anne. But the garrulous Anne does not usually occur. She only appears in some occasions. For instance, Matthew is a good listener and Anne id very fond of him. While staying with Matthew, Anne is always talkative. In addition, Diana is Anne's good friend. They always talk and play with each other. While playing with Marilla, Anne is also garrulous although it may make Marilla angry. But Anne is not always garrulous. For example, Anne does not like Bud Gill and never talk with him. In this case, Anne's agent language is changed with others, that is, the objects. Otherness is beneficial to agent's existence. And the agent's language is obvious. If otherness is not beneficial to agent's existence, the agent's language would be missing. The missing agent's language can further reflects the otherness influence of agent's existence, namely, agent's otherness existence. Agent is constructed in others' language.

\section{Author's Otherness Existence}

Discourse subject and statement subject. In perspective of psychoanalysis, complete "self-existence' is impossible. Human's existence can only be "otherness existence". (MA Yuanlong, 2006) Discourse subject is indicated by speakers in the text. It can be freely converted. Statement subject refers to of the discourse subject's imagined self-awareness. But that's just an illusion, (MA Yuanlong, 2004) that is, statement subject is consistently converted with discourse subject. However, statement subject does not correspond to discourse subject one by one. In our languages, only discourse subject can be analyzed. Based on Lacan's theory of unconsciousness, the narration of discourse subject in this novel should be emphasized. And the stress on others' languages shows the author's self-identity and reflects the trend of post-structure in literature.

Author's agent's otherness existence. Anne who has red hair is similar to Lucy Montgomery. They have the same family background and experiences. Montgomery was born in Clifton, a northern province of Prince Edward Island, Canada. When she was two years old, her mother died. Later, her mother left her and remarried. Little Montgomery had to live with her grandmother. Through others' language and discourse subject's narration in this novel, Montgomery imagines she is the statement subject and devotes her love to nature, her desire to love and better life to this novel. Annie says, "The Anne in Green Gables farmhouse is a hundred times better than that in any other place". Annie has closely contacted herself with the Green Gables farmhouse. Meanwhile, she realizes her otherness existence. Thereby, Montgomery realizes her own otherness existence through the otherness existence in her novel.

\section{Conclusions}

Anne of Green Gables is a classic work in children's literature. It has been researched by scholars from various angles for a long time. Mark Twain once said, "Annie is the most moving image following Alice who is the protagonist in Alice's Adventures in Wonderland. Whether the imaginative Anne, the Anne likes nominating, or the garrulous Anne, it gives people love and warmth, just as chicken soup for the soul. With the consistent object conversation and the release of unconscious power, the image of Anne's agent gradually plump up. Anne grows up in the story, and she continues to achieve her awareness of existence in others' world. While reading this novel, we grow up with Anne. In perspective of language culture, interpreting the identity of the protagonist in this novel and the author is also a literary criticism dimension of post-structuralism. And the post-structure emphasizes diversified analysis. Therefore, in the perspective of diversity, it is the free release of unconscious power between arbitrarily converted objects makes the awareness existence of agent's diversity possible. On one hand, in terms of structuralism, everything has structure. Thereby, Lacan proposed that unconsciousness also has structure, just like a language. This idea is influenced by structuralism. On the other hand, the approach to analyze unconscious phenomenon with structure 
has improved structuralism in the field of unconsciousness. (HUANG Zuo, 2001) If Lacan's theory of unconsciousness is the interaction between psychological unconsciousness and linguistic structure, this paper which analyzes literary identity is also a combination of unconsciousness and post-structuralism analysis. Overall, this paper combines psychology, linguistics and literature. It analyzes agent's otherness existence in Anne of Green Gables. It reflects the opposition and unity of structuralism and post-structuralism, which is sublimation in philosophy.

\section{References}

[1] HUANG Hanping. Lacan and Postmodern Cultural Criticism [M]. Beijing: China Social Sciences Press ,2006. ( 62).

[2] HUANG Zuo. On Lacan's Theory of the Unconscious [J]. SOCIAL SCIENCES ABROAD. 2001 (4): 45.

[3] MA Yuanlong. On Subversion of the Subject [J]. JOURNAL OF CENTRAL CHINA NORMAL UNIVERSITY (HUMANITIES AND SOCIAL SCIENCES). 2004, 43 (6): 48-55.

[4] MA Yuanlong. Author and/or the Other: An Introduction to the Lacanian Literary Theory [J]. FOREIGN LITERATURE. 2006 (01): 72-79.

[5] SUN Xiaoyu (translator). Anne of Green Gables [M]. Beijing: China Pictorial Publishing House, 2011.

[6] XIAO Jianrong. Summary Rewriting of Lacan's Psychoanalysis on Freud's Psychoanalytic Theory [J]. Journal of Southwest Agricultural University (Social Science Edition). 2013, 11 (06): 44-47.

[7] YANG Yan. The Long Way of Growth-up: A Study on Anne's Identity in Anne of Green Gables [J]. THE SCIENCE EDUCATION ARTICLE COLLECTS. 2008 (01): 151, 155.

[8] ZHAN Junfeng. Lacanian Psychoanalysis and Studies of Cultural Identity [J]. Journal of Xi'an Foreign Languages University. 2012, 20 (01): 21-23.

[9] ZHANG Yibing. Lacan:Symbolic Language--As a Corpse of Existence [J]. ZHEJIANG ACADEMIC JOURNAL. 2004 (6): 82-92.

[10] ZHANG Junmei. The Development of the Theory of Unconscious and Its Influences on Literature [J]. THEORY LEARNING. 2011 (4): 105. 